\title{
Effect of propolis extract on the parasite load of Nile tilapias reared in cages
}

\section{Influência do extrato de própolis na carga parasitária de tilápias do Nilo criadas em tanques-rede}

\author{
Elder Luis Buck ${ }^{1}$; Ivone Yurika Mizubuti²; Felipe Pinheiro de Souza ${ }^{3}$; Ricardo \\ Pereira Ribeiro ${ }^{4}$; Luiz Alexandre Filho ${ }^{4}$; Graciela Bracchini ${ }^{5}$; Odimári Pricila \\ Prado-Calixto $^{2}$; Angela Rocio Poveda-Parra ${ }^{6}$; Nelson Mauricio Lopera-Barrero ${ }^{2 *}$
}

\begin{abstract}
Due to increase in demand for healthy and chemical residue-free products, natural therapeutic substances are being enhanced in fish cultivation. Current study evaluates in an unprecedented way (Tesearchoxygen), the species is he effect of propolis on the parasite charge of the Nile tilapia (Oreochromis niloticus) reared in fish cages. Six hundred male Nile tilapia (200g) conditioned in ten $1 \mathrm{~m}^{3}$ cages were used. Two treatments with five replications each were provided: TCON: control (extruded meal without propolis) and TPRO: extruded meal with $4 \%$ propolis extract. Parasite collection occurred on 0, 35, 70 and 105 days. At the same time, fillet was weighed and fish standard length measured. Temperature was kept within the comfort range for the species during the experimental period $\left(>25^{\circ} \mathrm{C}\right)$. Trichodinids and Monogenoids (Dactylogyridae) were detected in the two treatments. There was no statistical difference $(\mathrm{p}>0.05)$ in mean parasite intensity (total parasites/specimens with parasites) and abundance (total parasites/examined specimens) among treatments in the four evaluation periods. Lowest parasite prevalence occurred after 70 days in TPRO (26.66\%). There was no statistical difference $(p>0.05)$ among treatments with regard to fillet weight and standard length of fish. Results show that propolis extract 4\% did not significantly affect parasite load, fillet weight and standard length of Nile tilapia.

Key words: Aquaculture. Oreochromis niloticus. Fish parasites. Natural products.
\end{abstract}

\section{Resumo}

Devido ao aumento da demanda por produtos saudáveis e livres de resíduos químicos, a utilização de terapêuticos naturais na criação de peixes tem sido cada vez mais estimulada. O objetivo do presente trabalho foi avaliar de forma inédita o efeito do extrato de própolis sobre a carga parasitária de tilápiasdo-Nilo (Oreochromis niloticus) criadas em tanque-rede. Foram utilizados 600 machos revertidos de tilápia-do-Nilo $(200 \mathrm{~g})$ acondicionados em 10 tanques-rede de $1 \mathrm{~m}^{3}$. Foram utilizados dois tratamentos com cinco repetições: TCON: controle (ração extrusada sem própolis) e TPRO: ração extrusada

\footnotetext{
${ }^{1}$ Dr. em Ciência Animal, Setor de rações animais, Cooperativa Integrada, Londrina, PR, Brasil. E-mail: elder.buck@integrada. coop.br

2 Profs. Drs., Departamento de Zootecnia, Programa de Pós-Graduação em Ciência Animal, Universidade Estadual de Londrina, UEL, Londrina, PR, Brasil.E-mail: mizubuti@uel.br, odimari@uel.br; nmlopera@uel.br

${ }^{3}$ Discente do Curso de Doutorado, Programa de Pós-Graduação em Ciência Animal, UEL, Londrina, PR, Brasil. E-mail: felipeps1991@gmail.com

${ }^{4}$ Prof. Dr., Departamento de Zootecnia, Programa de Pós-Graduação em Zootecnia, Universidade Estadual de Maringá, UEM, Maringá, PR, Brasil. E-mail: rpribeiro@uem.br, lafilho@uem.br

5 Prof ${ }^{a} \mathrm{Dr}^{\mathrm{a}}$, Curso de Agronegócio e Gastronomia, UNICESUMAR, Maringá, PR, Brasil. E-mail: gracielabh@ibest.com.br

${ }^{6}$ Pós-Doutoranda, Departamento de Zootecnia, UEL, Londrina, PR, Brasil. E-mail: angelapovedaparra@hotmail.com

* Author for correspondence
} 
contendo extrato de própolis a 4\%. As coletas de parasitas foram realizadas nos dias $0,35,70$ e 105 dias. Paralelamente, foi realizado a mensuração do peso do filé e comprimento padrão. A temperatura durante o período experimental se manteve dentro da faixa de conforto para a espécie. Foi verificada a presença de tricodinídeos e Monogenoides (Dactylogyridae) em ambos os tratamentos. Não houve diferença estatística $(\mathrm{p}>0,05)$ nos valores de intensidade (total de parasitas/número de indivíduos parasitados) e abundância (total de parasitas/total de indivíduos examinados) média parasitária entre os tratamentos nos quatro períodos de avaliação. A menor prevalência parasitária foi aos 70 dias em TPRO (26,66\%). Não foi constatada diferença estatística $(\mathrm{p}>0,05)$ entre os tratamentos na mensuração do peso do filé e comprimento padrão. Conclui-se que o extrato de própolis a 4\% não influenciou significativamente a carga parasitária, no peso do filé e no comprimento padrão em tilápias-do-Nilo.

Palavras-chave: Aquicultura. Oreochromis niloticus. Parasitas de peixe. Produtos naturais.

\section{Introduction}

Fish production in Brazil in 2015 reached 483,241 tons, totaling $\mathrm{R} \$ 3,064$ billion, with tilapia (Oreochromis niloticus) culture ranking first, or rather, $45.4 \%$ of total fresh-water fish production and high growth rates during the last decade (IBGE, 2015).

Great progress in tilapia production during the last few years is mainly due to several characteristics (white flesh, firm texture, nice taste, fillets without fish bones) featuring the species as one of the consumers most favorable fish. Since the tilapia adapts itself well to several and different environmental conditions (variations in temperature, $\mathrm{pH}$, salinity and dissolved oxygen), the species is also of interest for producers (EL-SAYED, 2006). However, the intensification of tilapia production has also triggered high density breeding systems with great risks related to diseases caused by stocking stress (KUBITZA, 2011). For instance, infestations by Tricodinids and Monogenoids parasites cause external lesions that become the gateway for bacteria, with significant mortality rates for fish (BRACCINI et al., 2008; JERÔNIMO et al., 2011; DOTTA et al., 2015).

Several antibiotics and anti-parasites agents have been employed to minimize the effects of disease on tilapia production and to decrease production liabilities. On the other hand, several products used are prohibited in countries where consumers give priority to high quality meat, food safety and products free from chemical residues (TELLI et al., 2014). Further, concern on the contamination of the environment is also present and research for alternative products is stimulated to lessen liabilities. Propolis, a natural product with therapeutic capacity (FISCHER, 2008), has been suggested to minimize the negative effects in fish production.

Propolis, an adhesive substance with a characteristic smell, is a resin collected by bees from fissures in tree barks, leaf buds and shoots (BANKOVA, 2005). Among its several chemical components, propolis may be highlighted for anti-parasite compounds, such as phenolic and flavonoid substances (HEINZEN et al., 2012), anti-inflammatory and antimicrobial compounds (FISCHER, 2008) and other active chemical ingredients (MARCUCCI, 1995). Although the employment of propolis in animals has had positive results against parasites (HEINZEN et al., 2012; MELLO-PEIXOTO et al., 2013), few studies have been undertaken to evaluate the effect of propolis against pathogens.

Since propolis extract as a diet supplement had provided positive results in growth performance, antimicrobial potential and immune-stimulant in fish (ABD-EL-RHMAN, 2009; DENG et al., 2011) and due to the growing demand by consumers for healthier and residue-free meat, the current study assesses (Tesearchoxygen), the species is he effect of propolis on the parasite charge of the Nile tilapia reared in fish cages. 


\section{Materials and Methods}

Place and experimental conditions

Current assay was performed on the Regional Campus of the Universidade Estadual de Maringá in Diamante do Norte PR Brazil, in the Rio do Corvo, an affluent of the River Paranapanema. The Rio do Corvo is a tributary of the Rosana Hydroelectric Reservoir, delimiting the municipalities of Diamante do Norte and Terra Rica, both in the state of Paraná, Brazil. Current research was approved by the Committee for Ethics in the Use of Animals of the Universidade Estadual de Londrina (Process 27941.2012.79).

Six hundred reversed male Nile tilapias (strain GIFT), initial weight $200 \mathrm{~g} \pm 25 \mathrm{~g}$ were used. Two treatments were evaluated: TCON - diet without propolis, with five replications (five $1 \mathrm{~m}^{3}$ cages; 60 fish per tank) and TPRO - diet with propolis with five replications (five $1 \mathrm{~m}^{3}$ cages; 60 fish per tank). Fish were acclimated for 10 days and four parasite samples were collected $(0,35,70$ and 105 days) in November, December (2013), January and February (2014), respectively. Mortality rate was calculated every day by individual observation for each cage and for each treatment.

Diet comprised an extruded commercial meal without propolis and a meal with $4 \%$ propolis extract (30\% crude protein; $5 \mathrm{~mm}$ diameter). Propolis extract was prepared with alcohol $4 \%$ by the Laboratory for the Development and Quality Control of Phytotherapics and Apitherapics of the Department of Pharmacy and Pharmacology of the Universidade Estadual de Maringá, Maringá PR Brazil, following protocol (adapted) by Franco and Bueno (1999). Propolis extract was added to the diet by direct aspersion and dried in the open air to remove alcohol excess. The product was placed in a dry and aired placed till use. Diet was provided three times a day at alternate periods.

\section{Temperature}

Mean water temperature was registered twice a day (09:00 and 18:00 h). Measurements were taken at three sites of the cage lines and at alternate lines.

\section{Analysis of parasites}

Procedures followed Braccini et al. (2008). Ectoparasites were determined by the scratching test involving the first branchial arc and left dorsal region of each fish previously anesthetized with benzocaine $\left(0,1 \mathrm{~g} \mathrm{~mL}^{-1}\right.$ alcohol $96^{\circ}$ into $10 \mathrm{~L}$ water). Each treatment comprised 15 animals (totaling 30 fish per harvest) in four harvests (totaling 60 fish per treatment). Scratching, visualized between the lamina and the cover slip $(22 \times 22 \mathrm{~mm})$ was performed by scalpel and magnified $100 \mathrm{x}$ under an optic microscope Olympus CBB. Material was disinfected with an iodine-based product $(2.6 \%$ iodine - $1000 \mathrm{ml}$ alcohol $96^{\circ}$ ) after each harvest.

\section{Weight of fillet and standard length}

Standard length (the distance from the tip of the lip till the caudal peduncle) was measured by caliper ruler. The fillet weight $(\mathrm{g})$ and standard length $(\mathrm{cm})$ were also measured. These measurements were performed at $0,35,70$ and 105 days. Animals were then insensitized with benzocaine $\left(0.1 \mathrm{~g} \mathrm{~mL}^{-1}\right.$ alcohol $96^{\circ}$ in $10 \mathrm{~L}$ of water); filleting was performed by technique involving the cutting of the head (dorsum-ventral direction), close to the opercula, and evisceration. Fillets were removed from the skeleton within a cranium-caudal and dorsumventral direction, one side at a time. The skin was removed in a caudal-cranial direction by tweezers and the fillets were cleaned by removing skin residues and fish bones in the cranial section. After cleaning, the fillets were weighed on a digital scale. Filleting was performed by the same researcher to avoid handling mistakes. 


\section{Data analysis}

Occurrence of ectoparasites was assessed qualitatively (presence orabsence) and quantitatively (the sum of the occurrence of parasites in the branchial filaments, skin or in both) of Trichodinids and Monogenoids (Dactylogyridae) in the two treatments. The number of fish with and without parasites was counted, coupled to the number of parasites in the branchiae and in the skin for each treatment to determine prevalence, intensity and abundance, following Bush et al. (1997). Results generated efficaciousness, according to Dotta et al. (2015) by formula: $\mathrm{E}=$ MNPCG - MNPTG x 100 / MNPCG (E: efficaciousness; MNPCG: number of parasites in control group; and MNPGT: number of parasites in the group with treatment). Results on parasite intensity and abundance underwent
Student's $t$ test $(\mathrm{p}>0.05)$. Results were compared according to treatment and cultivation days. Means of fillet weight and standard length were similarly analyzed, as those between treatments.

\section{Results}

Low mortality was reported in the assay with the two treatments (TCON: four fish; TPRO: two fish). Mean temperature rates of water were within the comfort zone for Nile tilapia (KUBITZA, 2000), above $25^{\circ} \mathrm{C}$ in most of the experimental period, except during the mornings in November $\left(24.8^{\circ} \mathrm{C}\right)$. Table 1 shows that mean general temperature of water ranged between $25.1^{\circ} \mathrm{C}$ (November) and $29.3^{\circ} \mathrm{C}$ (February).

Table 1. Mean water temperature $\left({ }^{\circ} \mathrm{C}\right)$ during the experimental period.

\begin{tabular}{cccc}
\hline \multirow{2}{*}{ Date } & \multicolumn{3}{c}{ Water temperature $\left({ }^{\mathbf{C}} \mathbf{C}\right)$} \\
\cline { 2 - 4 } & Morning & Afternoon & Mean \\
\hline Nov/2013 & $24.8 \pm 0.8$ & $25.3 \pm 1$ & $25.1 \pm 4.6$ \\
$\mathrm{Dec} / 2013$ & $27.2 \pm 1.0$ & $27.7 \pm 1.0$ & $27.4 \pm 0.9$ \\
$\mathrm{Jan} / 2014$ & $27.3 \pm 2.0$ & $27.8 \pm 1.1$ & $27.5 \pm 6.9$ \\
$\mathrm{Feb} / 2014$ & $28.7 \pm 0.4$ & $29.8 \pm 0.4$ & $29.3 \pm 0.3$ \\
\hline
\end{tabular}

Monogenoids in the branchiae and Trichodines in the tegument mucus occurred at the onset of the assay (day 0). As a rule, the two types of parasites during the four periods studied were restricted to a single tissue, or rather, Monogenoids in the branchial filaments and Trichodines in the tegument. The only exception occurred for the evaluation on the $35^{\text {th }}$ day with Trichodines on two sites in the two treatments. Highest prevalence rates $(\mathrm{P} \%)$ for parasite Trichodina were identified on the $35^{\text {th }}$ day in TCON and on the $105^{\text {th }}$ day in TPRO $(26.67 \%)$ (Table 2).
When total prevalence rates were analyzed (for the two parasites together), higher percentages were reported after 35 days $(46.66 \%)$ for the two treatments. There was no difference $(\mathrm{p}>0.05)$ in Mean Intensity (MI) between TCON and TPRO during the four periods analyzed. However, when only the evaluation days were taken into account, a significant rise in intensity rate occurred between the $70^{\text {th }}$ and $105^{\text {th }}$ days in both treatments. There was no difference $(\mathrm{p}>0.05)$ in mean abundance (MA) between treatments and between the evaluation periods (Table 3 ). 
Table 2. Prevalence of ectoparasites in the Nile tilapia (strain GIFT) for control treatment (TCON) and for treatment with propolis (TPRO) on $0,35,70$ and 105 days.

\begin{tabular}{|c|c|c|c|c|c|}
\hline \multirow{2}{*}{ Treatment (day) } & \multirow{2}{*}{ Parasite } & \multicolumn{2}{|c|}{ Branchiae } & \multicolumn{2}{|c|}{ Tegument } \\
\hline & & $\mathrm{PP} / \mathrm{PE}$ & $\mathrm{P}(\%)$ & $\mathrm{PP} / \mathrm{PE}$ & $\mathrm{P}(\%)$ \\
\hline \multirow{2}{*}{ TCON (0) } & Trichodina & $0 / 15$ & 0 & $2 / 15$ & 13.33 \\
\hline & Monogenoida & $2 / 15$ & 13.33 & $0 / 15$ & 0 \\
\hline \multirow{2}{*}{ TPRO (0) } & Trichodina & $0 / 15$ & 0 & $3 / 15$ & 20 \\
\hline & Monogenoida & $2 / 15$ & 13.33 & $0 / 15$ & 0 \\
\hline \multirow{2}{*}{ TCON (35) } & Trichodina & $1 / 15$ & 6.67 & $4 / 15$ & 26.67 \\
\hline & Monogenoida & $2 / 15$ & 13.33 & $0 / 15$ & 0 \\
\hline \multirow{2}{*}{ TPRO (35) } & Trichodina & $1 / 15$ & 6.67 & $3 / 15$ & 20 \\
\hline & Monogenoida & $3 / 15$ & 20 & $0 / 15$ & 0 \\
\hline \multirow{2}{*}{ TCON (70) } & Trichodina & $0 / 15$ & 0 & $2 / 15$ & 13.33 \\
\hline & Monogenoida & $3 / 15$ & 20 & $0 / 15$ & 0 \\
\hline \multirow{2}{*}{ TPRO (70) } & Trichodina & $0 / 15$ & 0 & $2 / 15$ & 13.33 \\
\hline & Monogenoida & $2 / 15$ & 13.33 & $0 / 15$ & 0 \\
\hline \multirow{2}{*}{ TCON (105) } & Trichodina & $0 / 15$ & 0 & $3 / 15$ & 20 \\
\hline & Monogenoida & $2 / 15$ & 13.33 & $0 / 15$ & 0 \\
\hline \multirow{2}{*}{ TPRO (105) } & Trichodina & $0 / 15$ & 0 & $4 / 15$ & 26.67 \\
\hline & Monogenoida & $2 / 15$ & 13.33 & $0 / 15$ & 0 \\
\hline
\end{tabular}

PP: fish with parasites; PE: examined fish; P(\%): Prevalence.

Table 3. Mean rates of prevalence ( $\mathrm{P} \%$ ), medium intensity (IM) and medium abundance (AM) of ectoparasites of the Nile tilapia for control treatment (TCON) and treatment with propolis (TPRO) on 0, 35, 70 and 105 days.

\begin{tabular}{|c|c|c|c|c|c|c|}
\hline & \multicolumn{3}{|c|}{ TCON } & \multicolumn{3}{|c|}{ TPRO } \\
\hline & $\mathrm{P} \%$ & IM & AM & $\mathrm{P} \%$ & IM & $\mathrm{AM}$ \\
\hline 0 Days & 26.66 & 4.5 (4.94) Aab & $0.6(0.7) \mathrm{Aa}$ & 33.33 & 3.92 (2) Aab & $0.7(0.59) \mathrm{Aa}$ \\
\hline 35 Days & 46.66 & 1.8 (1.13) Aab & $0.5(0.5) \mathrm{Aa}$ & 46.66 & $1.8(0.6) \mathrm{Aab}$ & $0.43(0.24) \mathrm{Aa}$ \\
\hline 70 Days & 33.33 & $1.66(0.47) \mathrm{Ab}$ & $0.27(0) \mathrm{Aa}$ & 26.66 & $1.5(0.7) \mathrm{Ab}$ & $0.2(0.09) \mathrm{Aa}$ \\
\hline 105 Days & 33.33 & $4.66(5.19) \mathrm{Aa}$ & $0.9(1.1) \mathrm{Aa}$ & 40 & $4.62(3.4) \mathrm{Aa}$ & $0.77(0.24) \mathrm{Aa}$ \\
\hline Mean & $35 \mathrm{~A}$ & $3.15(1.64) \mathrm{A}$ & $0.57(0.26) \mathrm{A}$ & $36.6 \mathrm{~A}$ & $2.96(1.54) \mathrm{A}$ & $0.525(0.26) \mathrm{A}$ \\
\hline
\end{tabular}

Capital letters indicate significant difference between treatments (TCON and TPRO); small letters indicate significant difference between different cultivation days by Student's $t$ test at $\mathrm{p}<0.05$.

Propolis-supplemented diet had the best efficaciousness on the $70^{\text {th }}$ day $(25 \%)$ when compared to evaluation rates on the $35^{\text {th }}$ and $105^{\text {th }}$ days (13.33 and 14.81\%, respectively) (Figure 1). There was no difference $(p>0.05)$ between fillet weight (g) and standard length $(\mathrm{cm})$ between treatments after 35,70 and 105 days. On the $70^{\text {th }}$ day, the two parameters were numerically higher in TPRO, although at the end of the assay (105 days), rates were higher in TCON (Table 4). 
Table 4. Fillet weight (g) and standard length (CP) of Nile tilapia for control treatment (TCON) and treatment with propolis (TPRO) on 35, 70 and 105 days.

\begin{tabular}{cccccc}
\hline & \multicolumn{2}{c}{ TCON } & & \multicolumn{2}{c}{ TPRO } \\
\cline { 2 - 3 } \cline { 5 - 6 } & Fillet $(\mathrm{g})$ & Standard length $(\mathrm{cm})$ & & Fillet $(\mathrm{g})$ & Standard length $(\mathrm{cm})$ \\
\hline 35 Days & $126(27.37)$ & $21.28(1.14)$ & & $126.27(18.01)$ & $21.29(0.98)$ \\
70 Days & $197.53(46.24)$ & $24.27(1.56)$ & & $217.6(35.23)$ & $24.94(1.09)$ \\
105 Days & $292.53(71.86)$ & $28.01(1.65)$ & & $259.33(73.86)$ & $27.05(1.68)$ \\
\hline
\end{tabular}

\section{Discussion}

Occurrence and intensity of ectoparasites in fish are correlated with eutrophication rates, diet management and adopted technology in productive systems. Conditions worsened when production intensified through high densities (TAVARESDIAS; MARIANO, 2015). Trichodines and monogenenoids in the Nile tilapia have already been detected in several fish farms with different stocking densities, cultivation phases and at different periods of the year (BRACCINI et al., 2008; JERÔNIMO et al., 2011; ZAGO et al., 2014; DOTTA et al., 2015; PAREDES-TRUJILLO et al., 2016). The above reveals that parasites always occur in culture conditions but are only relevant when there is an imbalance between host, parasite and environment.

High temperature during spring and summer enhances parasite infestation due to the improvement of proliferation conditions of fish pathogens (SCHALCH et al., 2005). On the other hand, suboptimal temperature conditions may reduce immune response and fish's capacity with regard to their response to antigens. Consequently, the animals are greatly susceptible to parasites. Braccini et al. (2008) analyzed the occurrence of ectoparasites of the Nile tilapia in the Rio do Corvo (the same river as that in current study) during May, June, July and August (mean water temperature at approximately $23^{\circ} \mathrm{C}$ ) and detected a slightly higher mean prevalence (38.2\%) when compared to that in current assay. The same authors also detected high ectoparasite prevalence at the start of the assay in May, although infestations decreased as fish grew up, with an increase of more than $25 \%$ in ectoparasites prevalence during the last month (August). Similarly, Marengoni et al. (2009) failed to report the relationship with monogenoids in the tilapias bred in cages between February and June, even though there was a greater temperature oscillation throughout the period. Contrastingly, Zago et al. (2014) reported an increase in mean intensity of ectoparasites according to the cultivation phase (initial, intermediate and final).

In spite of increase in mean temperature throughout the cultivation period detected in current assay, there was no relationship with parasite load, probably due to the fact that mean temperature in all periods remained within the species's comfort zone and management provided an adequate immunological response for pathogens. According to Kubitza (2000), tilapias cultivated at a temperature between 23 and $32^{\circ} \mathrm{C}$ tended to be less harmed by parasites since they lay between the thermal comfort boundaries for the species and, consequently, less susceptible to immunity decrease.

Due to its different therapeutic factors, such as anti-parasite (mainly phenolic and flavonoid compounds) (HEINZEN et al., 2012) and antiinflammatory substances (FISCHER, 2008), propolis added to diets provided good results against parasites in several animal species, such as mammals (MELLO-PEIXOTO et al., 2013) and fish. Dotta et al. (2015) analyzed the effect of diet supplementation composed of a mixture of propolis and Aloe barbadensis, between 15 and 21 days, and detected significant decrease in mean parasite intensity and prevalence in tilapias. Different from the above experiments, results in current analysis revealed that diet supplemented with propolis extract 
$4 \%$ failed to affect mean prevalence, occurrence and abundance of ectoparasites.

Lack of influence may be associated with the cultivation medium. Adequate temperature interval during the assay did not affect anti-parasite conditions of propolis contents since, within the best cultivation conditions (best temperature; low density), fish had sufficient immunological defense and probably responded naturally to the agents. It has been reported that propolis extract may increase bactericide activity in tilapias confronted with Aeromonas hydrophila by stimulating the defense cells (ABD-EL-RHMAN, 2009). Probably, in more challenging conditions within the environment, the therapeutic components of propolis act more significantly and efficaciously.

Efficaciousness should be underscored. Its rate was higher on the $70^{\text {th }}$ day when compared to that on the $105^{\text {th }}$ day. Dotta et al. (2015) found the same pattern between the $15^{\text {th }}$ and the $21^{\text {st }}$ day and attributed decrease to possible stress caused by animal density and product accumulation. However, in current research, the animal's age and immunity, environmental variations or pharmacological reactions due to the period in which propolis was employed may have decreased efficaciousness during the final period.

It seems that there was no difference between TCON and TPRO with regard to animals' age and immunity since mortality rate was low and animals grew homogeneously, when standard length was analyzed. According to Saha et al. (1999), the chronic use of phenolic compounds may reduce fish growth and development. The authors underscore that compounds enhance excessively mucus secretion on the skin and in the branchiae, causing difficulty in oxygen transport and, consequently, respiration capacity. Further, high concentration of these compounds may decrease the nutritional rates of the food when they interact with proteins, carbohydrates and minerals (SHAHIDI; NACZK, 1995). Consequently, the dispensation of propolis may have either triggered a chronic toxicity reaction or it interfered in nutrient absorption causing difficulties in the assimilation of propolis components after 70 days. Future studies are required to elucidate toxic concentrations and the manner the compounds' concentration affects the performance of the species.

Several researches on the effect of propolis in the diet have given satisfactory results on growth performance in fish (ABD-EL-RHMAN, 2009; DENG etal., 2011). However, no study has yet related the use of therapeutic products with biometric rates and the occurrence of parasites. Current assay failed to identify any statistical difference in intensity and abundance of ectoparasites, in fillet weight and in standard length between treatments on days 35,70 and 105.

Stress is a crucial factor in animal production with regard to animals zootechnical performance. Research with mammals have already underscored that propolis may have a positive effect on stressrelated biochemical responses (MISSIMA; SFORCIN, 2008). Since propolis decreases stress and parasite load, it may have affected fillet weight rates and standard length after 70 days. Further studies should be undertaken to elucidate this effect on fish and verify the mechanisms involved in antiparasite processes, performance and stress in cage conditions.

\section{Conclusions}

Propolis extract $4 \%$ did not affect mean parasite prevalence, intensity and abundance, fillet weight and standard length. A greater efficiency occurred on the parasite load after 70 days. Although a probable effect of the metabolic assimilation of propolis may have occur after 70 days of cultivation, further studies should be undertaken to elucidate other effects of the product on the cultivation of tilapias in cages. 


\section{Acknowledgments}

The authors would like to thank the Fundação Araucária for funding and for the scholarship and the Coperativa Integrada for donating the diets employed.

\section{References}

ABD-EL-RHMAN, A. M. M. Antagonism of Aeromonas hydrophila by propolis and its effect on the performance of Nile tilapia, Oreochromis niloticus. Fish Shellfish Immunology, London, v. 27, n. 3, p. 454-459, 2009.

BANKOVA, V. Recent trends and important developments in propolis research. Journal of EvidenceBased Complementary \& Alternative Medicine, Thousand Oaks, v. 2, n. 1, p. 29-32, 2005.

BRACCINI, G. L.; VARGAS, L.; RIBEIRO, R. P.; ALEXANDRE-FILHO, L.; DIGMAYER, $\mathrm{M}$. Ectoparasitos de tilápia do Nilo (Oreochromis niloticus) cultivados em tanques-rede nos rios do Corvo e Guairacá, Paraná, Brasil. Revista Brasileira de Parasitologia Veterinária, Jaboticabal, v. 17, p. 24-29, 2008. Suplemento 1.

BUSH, A. O.; LAFFERTY, K. D.; LOTZ, J. M.; SHOSTAK, A. W. Parasitology meets ecology on its own terms: Margolis et al. revisited. The Journal of Parasitology, Lawrence, v. 83, n. 4, p. 575-583, 1997.

DENG, J.; AN, Q.; BI, B.; WANG, Q.; KONG, L.; TAO, L.; ZHANG, X. Effect of ethanolic extract of propolis on growth performance and plasma biochemical parameters of rainbow trout (Oncorhynchus mykiss). Fish Physiology and Biochemistry, Amsterdam, v. 37, n. 4, p. 959-967, 2011.

DOTTA, G.; BRUM, A.; JERONIMO, G. T.; MARASCHIN, M.; MARTINS, M. L. Effect of dietary supplementation with propolis and Aloe barbadensis extracts on hematological parameters and parasitism in Nile tilapia. Revista Brasileira de Parasitologia Veterinária, Jaboticabal, v. 24, n. 1, p. 66-71, 2015.

EL-SAYED, A. F. M. Tilapia culture. Alexandria: Alexandria University, 2006. 277 p.

FISCHER, G.; HÜBNER, S. O.; VARGAS, G. D.; VIDOR, T. Imunomodulação pela própolis. Arquivos do Instituto Biológico, São Paulo, v. 75, n. 2, p. 247-253, 2008.

FRANCO, S. L.; BUENO, J. H. F. Otimização de processo extrativo de própolis. Infarma, Brasília, v. 11, n. 11-12, p. 48-51, 1999.
HEINZEN, E. L.; MELLO-PEIXOTO, E. C. T.; JARDIM, J. G.; GARCIA, R. C.; OLIVEIRA, N. T. E.; ORSI, R. $\mathrm{O}$. Extract of propolis in the control of helminthiasis in calves. Acta Veterinaria Brasilica, Mossoró, v. 6, n. 1, p. 40-44, 2012.

INSTITUTO BRASILEIRO DE GEOGRAFIA E ESTATÍSTICA - IBGE. Produção Pecuária Municipal 2015. Rio de Janeiro: IBGE, 2015. v. 43, 100 p.

JERÔNIMO, G. T.; SPECK, G. M.; CECHINEL, M. M.; GONÇALVES, E. L. T.; MARTINS, M. L. Seasonal variation on the ectoparasitic communities of Nile tilapia cultured in three regions in southern Brazil. Brazilian Journal of Biology, São Carlos, v. 71, n. 2, p. 365-373, 2011.

KUBITZA, F. Tilápia: tecnologia e planejamento na produção comercial. Jundiaí: F. Kubitza, 2000. 289 p.

2. ed. Jundiaí: Acqua Supre, 2011. 316

p.

MARCUCCI, M. C. Propolis: chemical composition, biological properties and therapeutic activity. Apidologie, Paris, v. 26, n. 2, p. 83-99, 1995.

MARENGONI, N. G.; SANTOS, R. S.; GONÇALVES JÚNIOR, A. C.; GINO, D. M.; ZERBINATTI, D. C.; LIMA, F. S. Monogenoidea (Dactylogyridae) em tilápias-do-nilo cultivadas sob diferentes densidades de estocagem em tanques-rede. Arquivo Brasileiro de Medicina Veterinária e Zootecnia, Belo Horizonte, v. 61, n. 2, p. 393-400, 2009.

MELLO-PEIXOTO, E. M.; ANDRADE, A.; VALADARES, F.; SILVA, L. Phytotherapy in the control of helminthiasis in animal production. African Journal of Agriculture Research, Lagos, v. 8, n. 21, p. 2421-2429, 2013.

MISSIMA, F.; SFORCIN, J. M. Green Brazilian propolis action on macrophages and lymphoid organs of chronically stressed mice. Journal of Evidence-Based Complementary \& Alternative Medicine, Thousand Oaks, v. 5, n. 1, p. 71-75, 2008.

PAREDES-TRUJILLO, A.; VELÁZQUEZABUNADER, I.; TORRES-IRINEO, E.; ROMERO, D.; VIDAL-MARTÍNEZ, V. M. Geographical distribution of protozoan and metazoan parasites of farmed Nile tilapia Oreochromis niloticus (L.) (Perciformes: Cichlidae) in Yucatán, México. Parasites \& Vectors, Prague, v. 9, n. 66, p. 1-16, 2016.

SAHA, N. C.; BHUNIA, F.; KAVIRAJ, A. Toxicity of phenol to fish and aquatic ecosystems. Archives of Environmental Contamination and Toxicology, New York, v. 63, n. 2, p. 195-202, 1999. 
SCHALCH, S. H. C.; MORAES, J. R. E.; MORAES, F. R. Fauna parasitária de peixes oriundos de pesquepague do município de Guariba, São Paulo, Brasil. Acta Scientiarum - Biological Sciences, Maringá, v. 28, n. 3, p. 291-297, 2005.

SHAHIDI, F.; NACZK, M. Food phenolics: sources, chemistry, effects and applications. Lancaster: Technomic Publishing Co., 1995. 576 p.

TAVARES-DIAS, M; MARIANO, W. S. Aquicultura no Brasil: novas perspectivas. São Carlos: Pedro \& João Editores, 2015. 429 p.
TELLI, G. S.; RANZANI-PAIVA, M. J. T.; DIAS, D. C.; SUSSEL, F. R.; ISHIKAWA, C. M.; TACHIBANA, L. Dietary administration of Bacillus subtilis on hematology and non-specific immunity of Nile tilapia Oreochromis niloticus raised at different stocking densities. Fish Shellfish Immunology, London, v. 39, n. 2, p. 305-11, 2014.

ZAGO, A. C.; FRANCESCHINI, L.; GARCIA, F.; SCHALCH, S. H. C.; GOZI, K. S.; SILVA, R. J. D. Ectoparasites of Nile tilapia (Oreochromis niloticus) in cage farming in a hydroelectric reservoir in Brazil. Revista Brasileira de Parasitologia Veterinária, Jaboticabal, v. 23, n. 2, p. 171-178, 2014. 
